\title{
IAMJ
}

INTERNATIONAL

AYURVEDIC

MEDICAL JOURNAL

Case Report

ISSN: 2320-5091

Impact Factor: 6.719

\section{A CASE STUDY ON MANAGEMENT OF KELOID WITH VIRECHANA}

\author{
$\underline{\text { Ashwini Anilkumar }}^{1}, \underline{\text { Veerakumara }}^{2}, \underline{\text { Nishanth }}^{3}, \underline{\text { Shrilatha Kamath }}^{4}$
}

${ }^{1}$ PG Scholar, Department of Kayachikitsa and Manasaroga SDM College of Ayurveda, Udupi, Karnataka, India ${ }^{2}$ Guide, Associate Professor, Department of Kayachikitsa and Manasaroga, SDM College of Ayurveda, Udupi, Karnataka, India

${ }^{3}$ Assistant Professor, Department of Kayachikitsa and Manasaroga, SDM College of Ayurveda, Udupi, Karnataka, India

${ }^{4}$ Professor, HOD, Department of Kayachikitsa and Manasaroga, SDM College of Ayurveda, Udupi, Karnataka, India

Corresponding Author: drashwinianilkumar@gmail.com

https://doi.org/10.46607/iamj3409052021

(Published Online: May 2021)

Open Access

(C) International Ayurvedic Medical Journal, India 2021

Article Received: 24/04/2021 - Peer Reviewed: 05/05/2021 - Accepted for Publication: 06/05/2021

Check for updates

\begin{abstract}
Keloid refers to irregularly shaped, thickened, firm, hypertrophic, pink or red lesion associated with tenderness, pain and pruritis which is generally due to fibroblast dysfunction. Wound healing is a complex process involving fibroblasts, profibroblast along with overproduction of type 1 procollagen which takes about 3 months to one year for its manifestation. Where the skin restores the lost tissues by scar formation and the new cell is supplied by new vasculature and incorporates new connective tissues. There is a change in the organization of the components from that of the dermis. Some develop it more often due to preceding injury, skin trauma, due to acne, folliculitis, burns, body piercings, surgical wounds or sometimes without a cause and this deregulation makes it difficult to cure and is associated with high rate of recurrence. Normal scars seem to have negative feedback mechanism where the fibroblasts are mobilized to repair their cutaneous defect. This negative feedback mechanism is defective in keloid formation. It has an effect on the aesthetic beauty concept which can create a mental agony too. Thus, keeping the versatility of Shodhana (purificatory measure) in mind, an attempt was done to manage the condition with Shodhana and marked changes were noted in the condition.
\end{abstract}


Keywords: Keloid, Vrana granthi, Shodhana,

\section{INTRODUCTION}

Keloid scar and hypertrophic scar are often confused. But it is important to be able to distinguish the two different pathological conditions. Keloid scars resemble hypertrophic scar superficially it is elevated but unlike hypertrophic scar they extend beyond the boundary of the original injury or incision. They can form within previous normal scar too. Often apparently in response to hormonal stimuli at the puberty or during pregnancy and diminishing sometimes after the menopause. Males and females are equally prone to keloid scars, but darker skin typed especially skin of African genetic origin are 15 times more prone. It involves abnormal collagen metabolism resulting in higher than usual proportion of type 3 collagen. They are more likely to form wounds that undergo inflammation without resolution for more than 3 weeks and are associated with tissue hypoxia and sustained level of transforming growth factor Beta 1 and 2 within the wound. Keloids contain thick collagen and have increased level of epidermal hyaluronic acid. ${ }^{1}$ Pressure from compressive dressings or clip on earrings increases collagenic activity and decreases collagen synthesis. Corticosteroids are used to decrease collagen synthesis. Cryotherapy and intralesional steroids injections are combined in treatment. Radiotherapy is also used but should be balanced against long term side effects . ${ }^{2}$

\section{CLASSIFICATION: ${ }^{3}$}

\section{CLINICO-MORPHOLOGICAL CLASSIFICA- TION:}

1.Acute

2.Subacute

3.Chronic

\section{ETIOLOGICAL CLASSIFICATION:}

1.Due to injury

2.Due to inflammation

3.Miscellaneous

\section{ACNE VULGARIS:}

Acne vulgaris is a chronic inflammatory disease of the pilosebaceous unit. It is due to androgen induced sebum production, altered keratinization, inflammation. These are present on face back, chest where it is more prone.
In Ayurvedic science, the condition of keloid can be studied under Vrana Granthi. ${ }^{5}$

Vitiated Doshas accumulating in Maamsa and Medo Dhatu along with Kapha accumulates forming Ggranthi and is Asadhya. ${ }^{6}$ incurable.Susrutha opines the same. ${ }^{7}$

\section{CASE REPORT: -}

\section{PRESENTING COMPLAINTS:}

A fifteen-year-old female c/o pink to reddish firm nodules on the right shoulder, upper back associated with itching in the last 5 years.

\section{ASSOCIATED COMPLAINTS:}

The complaints are associated with acne vulgaris since 5 years. The condition gets worsened during the menstrual phase.

\section{CASE HISTORY}

A fifteen-year-old young female who is $\mathrm{n} / \mathrm{k} / \mathrm{o}$ of HTN or DM was apparently fine five years ago. On attaining menarche, she developed acne vulgaris on and off which was found to be increasing with time and aggravated during the menstrual period especially. Later, she noticed a small reddish nodule on the right shoulder often pruritic and was gradually increasing in size. She had no h/o skin rashes or other skin ailments before its development. No h/o trauma, no h/o insect bite or any drug reaction were informed on interrogation. Lesion was firm, irregularly shaped, hyperpigmented erythematous nodules. Within a year it developed over both the upper limbs, spreading to the para sternal region, shoulder and also on the upper back. It was extensive, multiple, painless which was pinkish on eruption later turning to brown in color. Patient denied a positive history of the same in the family or any viral, autoimmune or other related pathological entity. She took allopathic and homeopathic treatment for the same for a short duration and had no much relief.

On interrogation:

* No history of trauma in the recent time of complaints.

* No history of allergy

* No history of insect bite. 
$\checkmark$ Birth-Uneventful, full term, normal vaginal delivery.

$\checkmark$ Childhood - uneventful, Milestones were attained on time. $\checkmark$ No history of chickenpox

$\checkmark$ No history of surgery, trauma

$\checkmark$ Took allopathic and homeo- medications for few weeks for same complaints, details not known.

\section{GENERAL EXAMINATION \\ EXAMINATION(AYURVEDIC) \\ Nadi(pulse)-89/min \\ Mala(body waste)-prakruta \\ Mutra(Urine)-samyak, 4-5 times/day \\ Jihwa(Tounge)-upalipta \\ Shabda(Voice)-prakrita \\ Sparsha(Touch)-Ruksha \\ $\operatorname{Druk(Eye~sight)-prakrita}$ \\ Akruti-Prakruta \\ Sara,satva,samhanana-madhyama \\ Ahara Shakti,vyayama shakti-Prakruta}

\section{GENERAL EXAMINATION}

Pallor-present

Icterus-absent

Lymph nodes-palpable

Clubbing-absent

Oedema-absent

\section{SYSTEMIC EXAMINATION:}

\section{CNS \\ RS \\ CVS \\ $\mathrm{P} / \mathrm{A}$}

Integumentary system examination

Musculoskeletal examination
HMF-Intact, cranial nerve examination-normal

NVBS heard

S1 S2 heard

Soft, non-tender, no organo megaly

Affected

Muscle power-5/5 bilateral upper and lower limbs.

Normotonic.

\section{LOCAL EXAMINATION}

\section{Integumentary system:}

Site of lesion

Distribution

Symmetry

Secondary lesion

Colour

Discharge

Odour

Associated features

Surrounding skin

Tenderness over the bilateral upper limbs, chest and lower limbs.

Generalised

Asymmetrical distribution

excessive scarring

initially pinkish-reddish, later brownish discolouration

Absent

Absent

Itching

Reddish discoloration

Present 


\section{NIDANA PANCHAKA:}

Dosha involved-vata kapha

Aharaja nidana (Dietary cause)- Regular intake of Maamsa, Matsya Aahara. (Non-vegetarian food)

Daily intake of curd, fermented food like idly, dosa etc. More affinity to fried and processed food.

Viharaja Nidana_(Lifestyle cause)-Sedentary lifestyle, Diwaswapna (day sleep), Alpacheshta (less physical activities).
Poorvaroopa (premonitory symptom)- Kandu (Itching) Roopa (symptoms)-Elevated brownish nodular lesion on the $\mathrm{B} / \mathrm{L}$ upper and lower limbs and chest

Upashaya- medication

Anupashaya- Menstruation, stress

DIAGNOSIS: Keloid/Vranagrandhi due to repeated acne vulgaris.

\section{INTERVENTION:}

\begin{tabular}{|l|l|}
\hline $20 / 12 / 2020$ & Chitrakadi Vati 2 TID \\
\hline From 21/12/2020 & Snehapana with Anabhishyandi Ghrita for 7 days. \\
\hline For next 3 days & Nimbapatra Parisheka and Abhyanga with Danta Pala Taila. \\
\hline $29 / 12 / 20$ & Madhyama Shudhi was attained and was followed with Samsarjana Krama \\
\hline
\end{tabular}

* Subjective changes symptoms of itching and discomfort were reduced according to the patient.

*Objective changes-decrease in the size of lesions were observed.

\section{VANCOUVER SCAR SCALE:}

\begin{tabular}{|l|l|l|}
\hline VASCULARITY & BT & AT \\
\hline Normal & 1 & 1 \\
\hline Pink & & \\
\hline Red & & \\
\hline Purple & 1 & 1 \\
\hline PIGMENTATION & & \\
\hline Normal & & \\
\hline Hypopigmentation & & \\
\hline Hyperpigmentation & & 2 \\
\hline PLIABILITY & 3 & \\
\hline Normal & & \\
\hline Supple & & \\
\hline Yielding & & \\
\hline Firm & & \\
\hline Ropes & & \\
\hline Contractures & 2 & \\
\hline HEIGHT mm & & \\
\hline Flat & 7 & \\
\hline$<2$ & & \\
\hline $2-5$ & & \\
\hline$>5$ & & \\
\hline Total score & & \\
\hline
\end{tabular}




\begin{tabular}{|l|l|l|}
\hline MANCHESTER SCAR SCALE & & \\
\hline COLOUR & 3 & 2 \\
\hline Matte vs shiny & 2 & 1 \\
\hline Contour & 4 & 4 \\
\hline Distortion & 3 & 2 \\
\hline Texture & 4 & 3 \\
\hline Total score & 16 & 12 \\
\hline
\end{tabular}
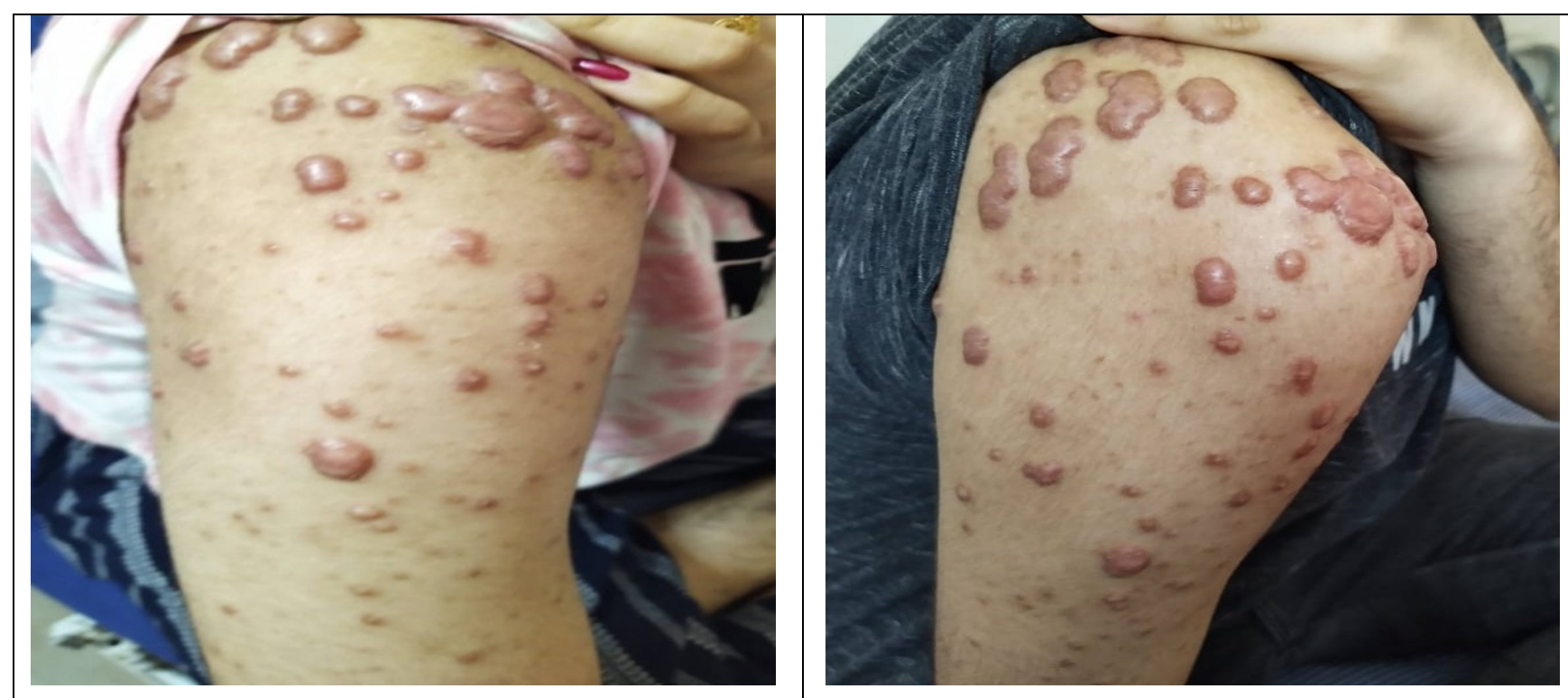

\section{DISCUSSION}

Keloids are benign proliferative growth of dermal collagen that usually result from the excessive tissue response to skin trauma in predisposed individual. The balance between collagen synthesis and degradation is maintained by matrix. The general management of the condition is said to be Compression therapy, cryotherapy, laser therapy, surgical excision, where the aim lies in correction of the abnormal balance of collagen synthesis and degeneration by altering the immune inflammatory response. In condition of extreme overgrowth of scar tissue beyond the limits of the original wound and shows no tendency to resolve. On attempt to manage the condition with Shodhana treatment like Virechana, which is said to restore the normal functioning of Sapta dhatus at Dhatwagni level help to bring the pathological process under control. Thus, an attempt was done with Anabhishyanta Ghrita Snehapana followed by Virechana which showed up a mild change which was documented here.

\section{CONCLUSION}

Keloid being a condition which is not just physical but also causing a mental agony, having back minimal management strategies, and on execution of the condition with standard Shodhana procedure with Anabhishyanda Grita followed by virechana showed mild changes which has significant changes in the parameters as mentioned above.

\section{REFERENCES}

1. Henry Hamilton Bailey, Bailey and love's, Wounds, Hodder Arnold, London,24 ${ }^{\text {th }}$ ed R.C.G. Russell 2004 p1522

2. Henry Hamilton Bailey, Bailey and love's, Wounds, Hodder Arnold, London,24 ${ }^{\text {th }}$ ed R.C.G. Russell 2004 p1522.

3. Butler PD Longaker MT Yang G. P current progress in keloid research and treatment. JAMCOLL: surg.2008:206(4):731-741(pubmed article) 
4. Robaee A. Assessment of general health and quality of life in patients with acne using validated generic questionnaire. Acta dermatoven APA.2009.[Pubmed]

5. Vaidya Yadavji Trikamji Acharya, Charaka Samhita of Agnivesha elaborated by charaka and drudhabala with Ayurveda Dipika Commentary by Chakrapanidatta, Varanasi Choukambha Surabharati Prakashan, Reprinted 2005 Chikitsa sthan 12-81.

6. 6.Pt. Hari Sadashiva Shastri Paradkar Ashtanga Hridaya of Vagbhata Annotated by Dr. Anna Kunte and Krishna Narve, Varanasi Chaukambha Surbharathi prakashan, Reprinted 2002 Uttarsthan 29-14.

7. Anantaram Sharma, Susrutha Samhita, Varanasi, Choukambha Surabharathi Prakashan, $1^{\text {st }}$ Edition 2001 Sutra sthana 17-29.

8. Arnold HL, Graver FH. etiology and management by excision and intensive prophylactic radiation. Arch Dermatol 1959; 80:772.

\section{Source of Support: Nil \\ Conflict of Interest: None Declared}

How to cite this URL: Ashwini Anilkumar et al: A Case Study On Management Of Keloid With Virechana. International Ayurvedic Medical Journal \{online\} 2021 \{cited May, 2021\} Available

$\underline{\text { http://www.iamj.in/posts/images/upload/1141_1146.pdf }}$ 